\title{
Geometric Features of Vertebrobasilar Arterial System in Adult Black Kenyans
}

\author{
Características Geométricas del Sistema Arterial Vertebrobasilar en Kenianos Negros Adultos
}

\author{
Julius A. Ogeng'o; Philip M. Mwachaka; Dan E. Odhiambo; Simeon R. Sinkeet \\ Hemed Elbusaidy; Beda Olabu \& Martin Inyimili
}

OGENG'O, J. A.; MWACHAKA, P. M.; ODHIAMBO, D. E.; SINKEET, S. R.; ELBUSAIDY, H.; OLABU, B. \& INYIMILI, M. Geometric features of vertebrobasilar arterial system in adult black Kenyans. Int. J. Morphol., 36(2):544-550, 2018.

SUMMARY: Geometric features of vertebrobasilar system influence occurrence of posterior circulation atherosclerosis, aneurysms, stroke and neuroradiological procedures. These features show ethnic variation, but data from black Africans in Sub Saharan Africa are scarce. This study aimed to describe geometric features of vertebrobasilar system in a black Kenyan population. It was a descriptive cadaveric study at Department of Human Anatomy, University of Nairobi. One hundred and seventy three formalin-fixed adult brains of individuals (99 male; 74 female; Age range 20 - 79) who had died of non cerebrovascular causes were studied. Level and angle of confluence of vertebral artery; diameter, length and bifurcation angles of basilar artery were measured. Data were analysed by SPSS version 21 for windows. The student $\mathrm{t}$ - test was used to determine the sex differences at $95 \%$ confidence interval. Data are presented in macrographs, tables and bar charts. Confluence of vertebral arteries occurred at the sulcus bulbopontinus in $79.8 \%$; rostral to it in $11.5 \%$ and caudal to it in $8.7 \%$ of cases. Mean angle of vertebral artery confluence was $46.7^{\circ}$ and $68.9^{\circ}$ in males and females respectively ( $\mathrm{p} \leq 0.042$ ). Mean length of the basilar artery was $26.8 \mathrm{~mm} ; 26.3 \mathrm{~mm}$ in males and $27.1 \mathrm{~mm}$ in females ( $\mathrm{p}=0.465)$. Mean diameter was $3.52 \mathrm{~mm} ; 3.32 \mathrm{~mm}$ in males and $3.72 \mathrm{~mm}$ in females ( $\mathrm{p}=0.002)$. The mean angle of basilar artery bifurcation was $120.3^{\circ} \pm$ $15.2 ; 99.3^{\circ} \pm 32.9$ in males and $140.3^{\circ} \pm 16.1$ in females $(\mathrm{p}=0.024)$. It was wider than $90^{\circ}$ in $82.9 \%$ of males and $95.9 \%$ females ( $\mathrm{p}=0.032)$. In $85(49.1 \%)$ it was wider than $120^{\circ}$. The vertebrobasilar system in the Kenyan population has geometric features that constitute risk factors for atherosclerosis. These features display sex dimorphism which may explain differences in prevalence of atherosclerosis and aneurysms. Neurosurgeons and neurologists should be aware of these differences. Individuals with risk prone geometric features should be followed up for atherosclerosis.

KEY WORDS: Vertebrobasilar system; Geometry; Sexual dimorphism; Africans.

\section{INTRODUCTION}

The basilar artery (BA), formed by confluence of two vertebral arteries (VA), constitutes the spine of posterior cerebral circulation, which supplies the brainstem, cerebellum, temporal and occipital lobes of the cerebrum. Its atherothrombosis can lead to infarction of the brainstem and cerebellum, which comprise $20 \%$ of all ischemic strokes (Bamford et al., 1991). It is, among intracranial arteries, one of the first and most severely involved artery in atherosclerosis (Oladapo et al., 2013). Its geometric features influence the occurrence of atherosclerosis and aneurysms (Efendic' et al., 2014). These parameters are also important for design, selection of, and molding devices during interventional neuroradiological procedures as well as mitigating complications of endovascular treatment, prognostication of cerebrovascular disease, during surgical, diagnostic and interventional radiological procedures (Wankhede et al., 2014).

Vascular geometry shows ethnic variation (Koch et al., 2009). As stroke becomes more common in African countries (Owolabi et al., 2015), there is greater need for local data on vascular geometry to inform its management in the posterior circulation. Reports on geometric features from black African populations, however, remain scarce. This study, therefore, investigated geometric features of vertebrobasilar system in an adult black Kenyan population. 


\section{MATERIAL AND METHOD}

One hundred and seventy three brains from adults [99 males; 74 females, age range $20-79$ years] were examined at the Department of Human Anatomy, University of Nairobi, Kenya. The Kenyatta National Hospital Ethics and Research Committee granted ethical approval. Brains were weighed and divided into male and females groups. The arachnoid mater was then gently peeled off the brainstem to expose vertebral and basilar arteries. Angles of confluence and bifurcation were measured to the nearest point five. The level of confluence was taken relative to the bulbo pontine junction. Internal diameter of the basilar artery was measured from haematoxylin/Eosin stained microscopic sections. In these cases, using a scion $\odot$ image analyzer, the internal circumference was determined and diameter in millimeters calculated from the formula

$$
\mathrm{D}=\frac{\mathrm{C}}{\pi}
$$

where $\mathrm{D}=$ diameter, $\mathrm{C}=$ circumference and $\pi=3.14$.

Length of basilar artery was measured between the point of confluence and that of bifurcation by two independent investigators, and the average to the nearest point five taken.

Data were analyzed using SPSS version 21.0 for Windows. Sex differences were analysed using the student t-test at $95 \%$ confidence intervals where $p$ value $\leq 0.05$ was taken as significant. Results are presented in macrographs, tables and bar graphs.

\section{RESULTS}

The mean weight of the brains was $1250 \mathrm{~g}$ (Range $1140-1450 \mathrm{~g}$ ). The mean for males was $1265 \mathrm{~g}$ while that of females was $1230 \mathrm{~g}$. The difference was not statistically significant $(p=0.064)$. In all the samples studied, the basilar artery was formed by union of two vertebral arteries. There were wide variations in level and angles of confluence and bifurcation, as well as in diameter and length.

Level and angle of confluence of vertebral arteries. In relation to the sulcus bulbopontinus, all the vertebral arteries united within $1.5 \mathrm{~cm}$ of it: $79.8 \%$ united at, $11.5 \%$ rostral and $8.7 \%$ caudal to the junction. The mean angle of confluence was $46.7^{\circ} \pm 17.7$ [range $20-100$ ] and $68.9^{\circ} \pm$ 13.8 [range $31-90$ ], in males and females respectively [ $=0.042]$. The angle was less than $30^{\circ}$ in $13.1 \%$ of males and none of females, and greater than $60^{\circ}$ in $5 \%$ of males and $58.1 \%$ of females (Fig. 1).

Some examples of angles and level of confluence are depicted in Figure 2.

Length and diameter of basilar artery. The overall mean length was $26.8 \pm 1.7 \mathrm{~mm}$ (Table I). It was different between males and females. In males, the mean length of the basilar artery was $26.3 \mathrm{~mm}$ while in females it was $27.1 \mathrm{~mm}$ in females $(\mathrm{p}=0.465)$. Thirteen $(13.1 \%)$ of males and 11 (14.9 $\%$ ) of females had length $>30 \mathrm{~mm}$. The sex difference was statistically significant $(\mathrm{p}=0.015)$.

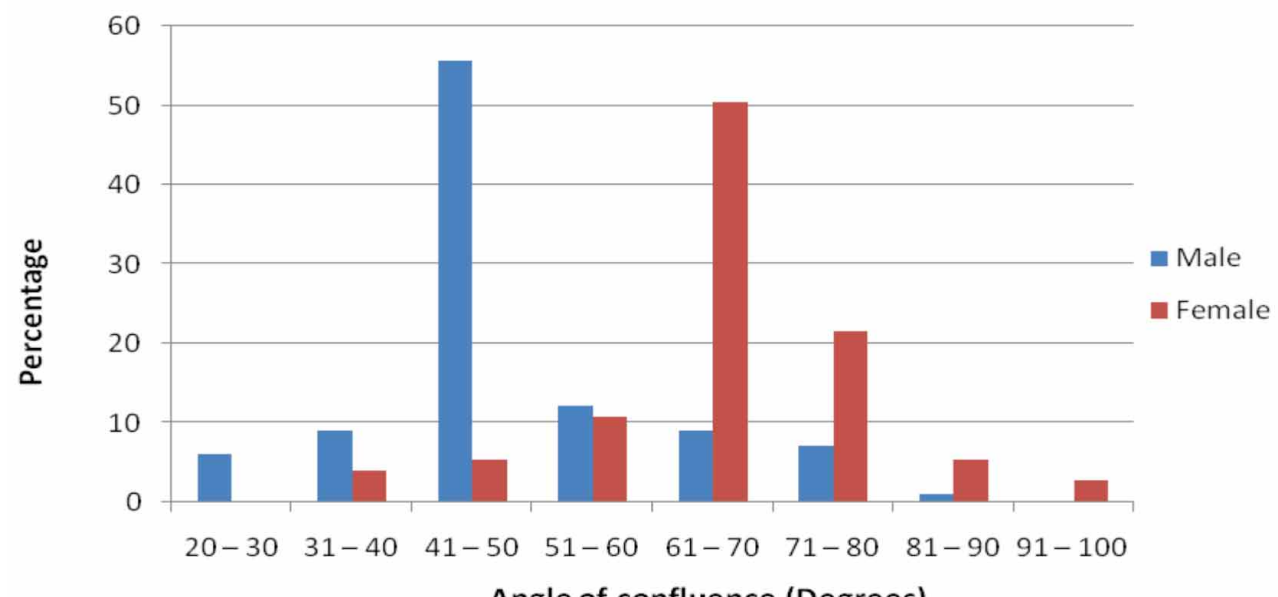

Fig. 1. Distribution of angles of confluence. 
Table I. Length of basilar artery in black Kenyans.

\begin{tabular}{lcll}
\hline Range & $\begin{array}{c}\text { Length }(\mathrm{mm}) \\
\text { Male }\end{array}$ & Female & Total \\
\hline $15-20$ & 10 & 6 & 16 \\
$21-25$ & 65 & 43 & 108 \\
$26-30$ & 12 & 15 & 27 \\
$31-35$ & 8 & 7 & 15 \\
$36-40$ & 4 & 3 & 7 \\
Total & 99 & 74 & 173 \\
Mean & 26.3 & 27.1 & 26.8 \\
\hline
\end{tabular}

Mean diameter was $3.52 \mathrm{~mm} ; 3.32 \pm 1 \mathrm{~mm}$ in males and $3.72 \mathrm{~mm} \pm 0.5 \mathrm{in}$ females. The difference was statistically significant $[\mathrm{p}=0.002]$.

Ten $(13.5 \%)$ of the females had diameter $\geq 4.5 \mathrm{~mm}$, but no males had a diameter $>4.0 \mathrm{~mm}$. Majority of the cases had diameter between 2.5 and $4.0 \mathrm{~mm}$ (Fig. 3).
Level and angle of basilar artery bifurcation. Most (164; $94.8 \%$ ) terminated at the ponto-mesencephalic junction. Only $9(5.2 \%)$ terminated rostral to the pontomesencephalic junction. There were no cases of caudal termination. All the 9 cases had caudal confluence. The mean angle of bifurcation was $99.88^{\circ} \pm 32.85$ [range $45-150^{\circ}$ ] in males and $140.26 \pm 16.07$ [range $75-165$ ] in females [ $\mathrm{p}=0.024$ ] It was wider than $90^{\circ}$ in $82.9 \%$ of males and in $95.9 \%$ of females (Fig. 4). The difference was statistically significant $(\mathrm{p}=0.032)$. In $85(49.1 \%)$, it was above $120^{\circ}$ (Fig. 5).

Examples of angles and levels of basilar artery bifurcation are shown in Figure 4 (A, B). Besides wide and narrow angles, two other features were observed namely 5 cases where the basilar artery appeared to continue into one of the posterior communicating arteries (Fig. 4C) and 4 cases in which there was a $\mathrm{U}$ - shaped bifurcation (Fig. 4D).
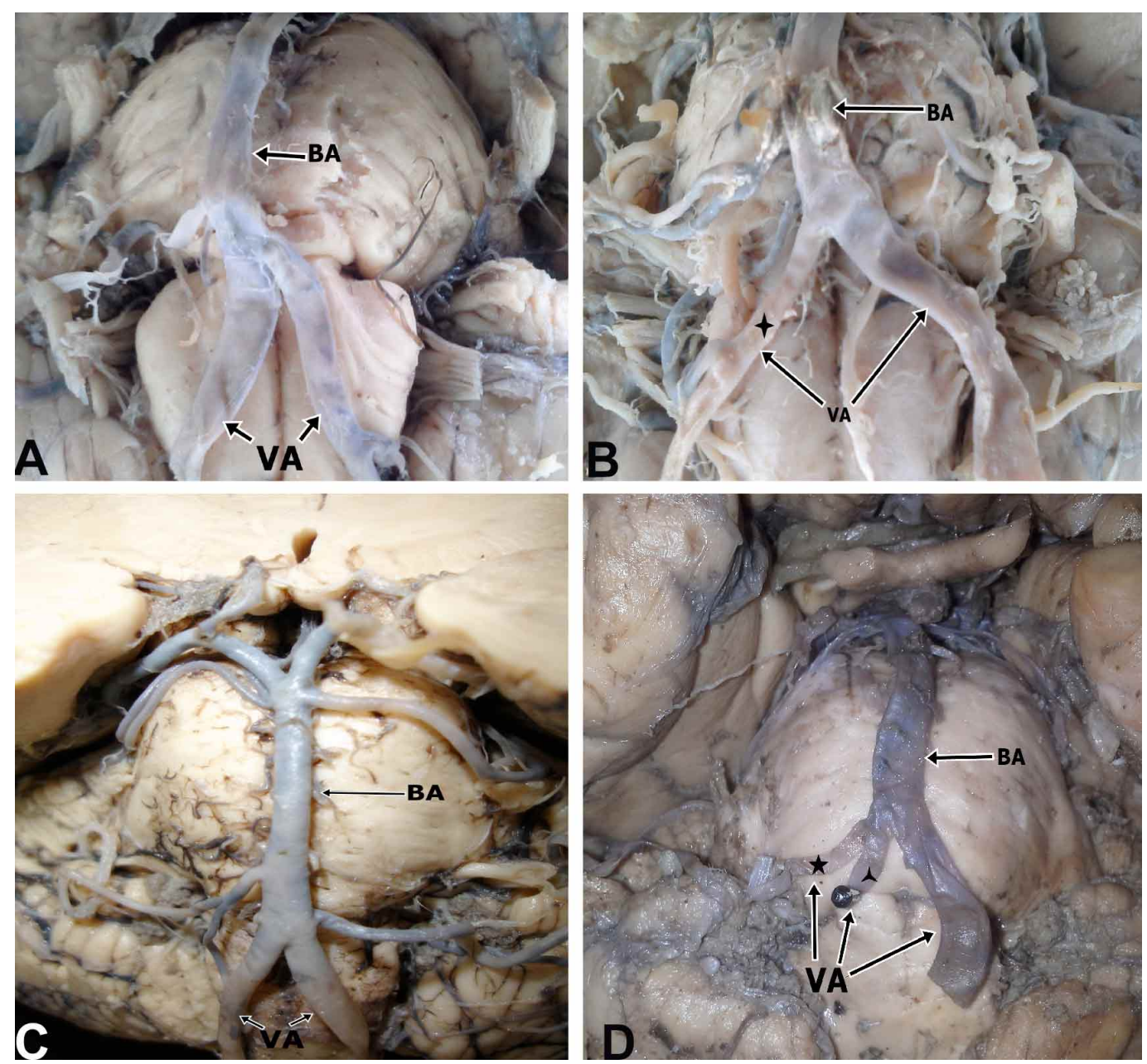

Fig. 2. Macrographs depicting angles and levels of vertebral artery confluence. $B A=$ Basilar artery; VA= Vertebral Artery; A - Narrow angle confluence $\left(20^{\circ}\right)$; B - Wide angle confluence $\left(70^{\circ}\right)$. Note vertebral artery hypoplasia (star); C - Confluence caudal to sulcus bulbopontinus; D - Confluence rostral to sulcus bulbopontinus. Note also, VAH, Curvature and dolichoectasia of BA and VA. 


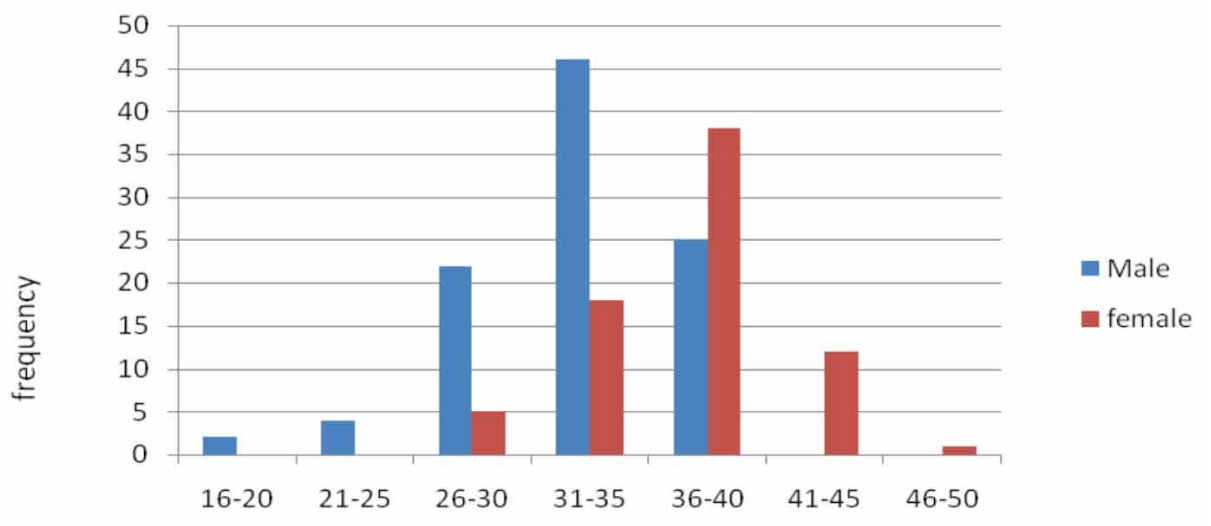

diameter $(\mathrm{mm}) \times 10$

Fig. 3. Diameter of basilar artery.
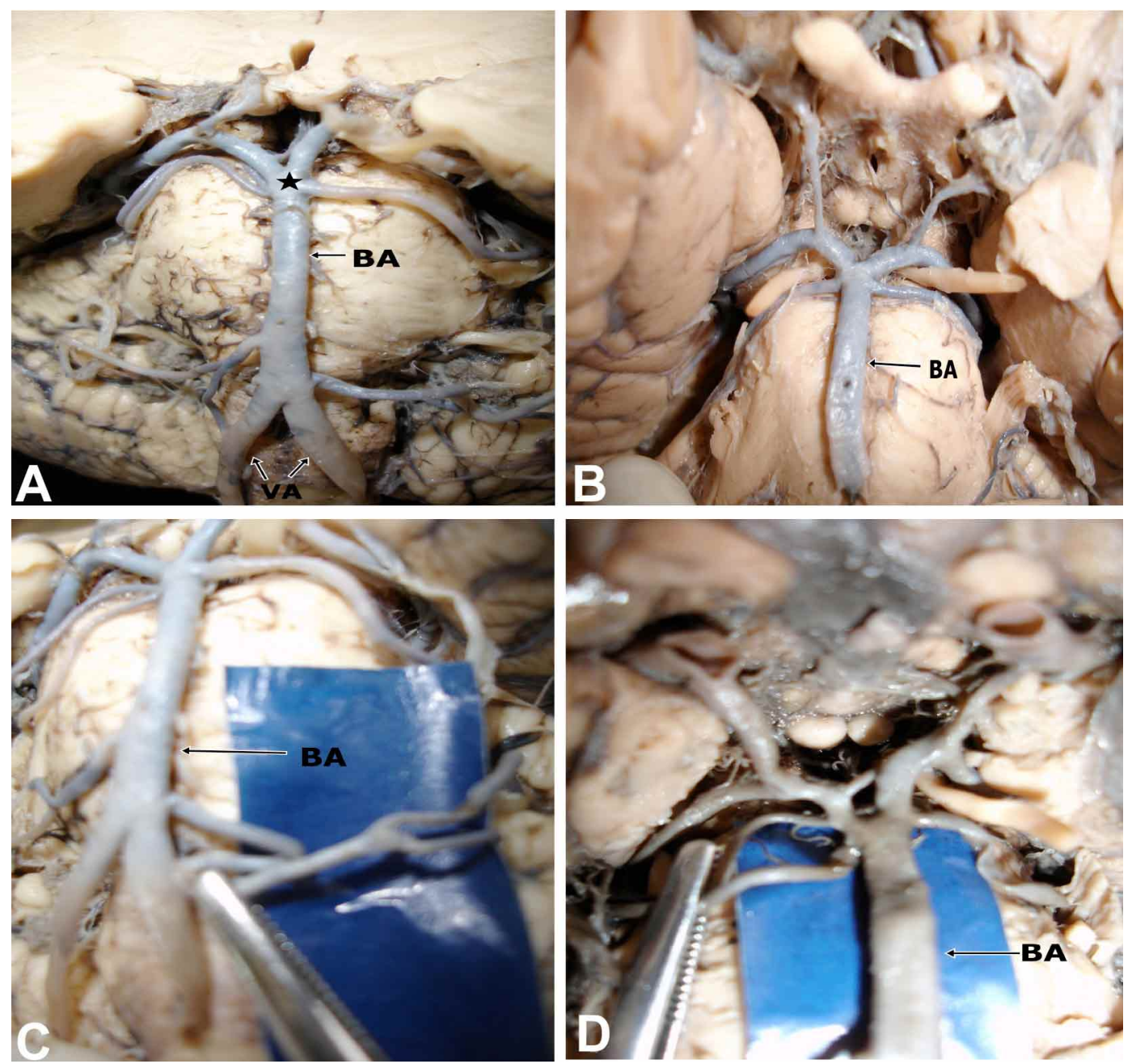

Fig. 4. Types and angles of basilar artery bifurcation in a black Kenyan population. A: Narrow (BA) bifurcation angle. Note the bifurcation at ponto-mesencephalic junction; B: Wide BA bifurcation angle; C: BA continuing as left posterior cerebral artery. Note termination rostral to ponto - mesencephalic junction; D: $\mathrm{U}$ - shaped termination 


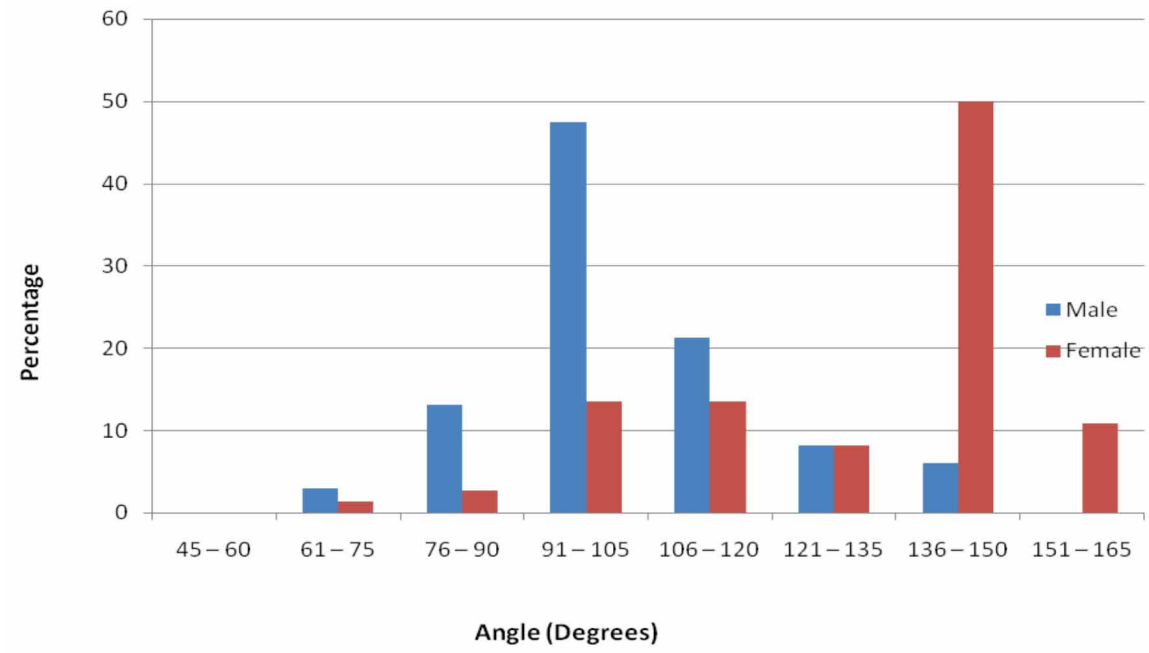

Fig. 5. Angle of Basilar artery bifurcation

\section{DISCUSSION}

Geometric features of vertebrobasilar system show a wide range of variations, consistent with prevailing literature from other populations (Songur et al., 2008; Efendic et al.). These variations may influence hemodynamics and hence preponderance to atherosclerosis and aneurysm (Efendic et $a l$.$) .$

Level and angle of vertebral artery confluence. Level of confluence is important during basilar artery instrumentation. Observations of the current study reveal that in the majority $(79.8 \%)$, confluence occurred at the sulcus bulbopontinus, much higher than in the Polish and Turkish populations where $44.4 \%$ and $20 \%$ terminated at the sulcus bulbopontinus, 40 $\%$ and $67 \%$ caudal, and $15 \%$ and $12 \%$ rostral to it respectively (Wójtowitz et al., 1989; Songur et al.). It was nonetheless similar to the Indian population where $88.3 \%$ cases terminated at the sulcus bulbopontinus (Patel et al., 2015). Design and use of instruments should bear this in mind.

Angle of confluence plays an important role in the location of atherosclerosis (Glagov et al., 1988). The angle of confluence averaging $46^{\circ}$ in males and $68.9^{\circ}$ in females is concordant with literature reports that it varies between $10^{\circ}$ and $160^{\circ}$ (Ravensbergen et al., 1996). Large angles of confluence are geometric risk factors for atherosclerosis. Accordingly, the $21.4 \%$ of Kenyan sample in whom the angle is larger than $75^{\circ}$ and especially the females may be more susceptible to atherosclerosis of the vertebrobasilar junction.

Length and diameter of basilar artery. Basilar artery geometry strongly influences both skewing of the velocity profiles, wall shear stress distribution and progression of atherosclerosis (Lee et al., 2012). Length of basilar artery ranges $24.8-38.5 \mathrm{~mm}$ (Dodevski et al., 2011). The average length was $26.8 \mathrm{~mm}$, lower than $33 \mathrm{~mm}$ reported for the Polish study (Wójtowitz et al.) but higher than 23.5 - 24.9 reported from Japanese and Indian studies (Pai et al., 2007; Tanaka et al., 2013) (Table II).

BA dilatation is associated with both large artery atherosclerosis and cerebral small vessel disease such as lacunar infarcts, and deep white matter lesions (Ichikawa et $a l ., 2011)$. It is also related with aging and atherosclerotic risk factors (Ikeda et al., 2010), intracranial bleeding, stroke mortality and cardiovascular death (Ubogu \& Zaidat, 2014). Increase in the diameter of BA increases risk of cerebrovascular events by 1.55 (Tanaka et al.). The average diameter of 3.32 $\mathrm{mm}$ falls within the range of $3.3-4.5 \mathrm{~mm}$ reported in literature (Table II).

A remarkable finding of the current study is that 24 $(11 \%)$ of arteries were longer than $29.5 \mathrm{~mm}$. Out of these 11 (6.4\% of total) were wider than $4.5 \mathrm{~mm}$ and curved. They would therefore be considered to be dolichoectasic (Ubogu \& Zaidat). This (6.4\%) is higher than 0.06-5.8 \% reported in prevailing literature (Xu et al., 2014). Notably, it is higher than $4.4 \%$ reported among an American population (Ubogu \& Zaidat) and 0.8-1.3 among Japanese (Tanaka et al.). The high incidence of dolichoectasia suggests a higher propensity to atherosclerotic cerebrovascular disease.

Length and diameter show wide diversity, probably 
Table II. Mean lengths and diameter of basilar artery reported in literature.

\begin{tabular}{llll}
\hline Author & Population & Length $(\mathrm{mm})$ & Diameter $(\mathrm{mm})$ \\
\hline Wojtowitz et al., 1989 & Polish & 33 & $>4$ \\
Pai et al., 2007 & Indian & 24.9 & 4.3 \\
Tanaka et al., 2013 & Japanese & - & 2.7 \\
Efendic et al., 2014 & Bosnian & - & 3.8 \\
Current study & Kenyan & 26.8 & 3.32 \\
\hline
\end{tabular}

due to methodological or ethnic differences. The latter may explain reported ethnic variation in basilar artery occlusive disease. These measurements are also important in prognosticating cerebrovascular disease. For example, basilar artery diameter $>4.5 \mathrm{~mm}$ may be a marker for a high risk of fatal stroke (Pico et al., 2006). In the current study, over $6.4 \%$ of individuals and over $10 \%$ of females had diameters $>4.5 \mathrm{~mm}$, implying that if they suffered brain infarction, they would be at risk of high mortality. Basilar artery diameter may also influence neurological outcome in acute pontine infarction (Aoki et al., 2010). The diameters are also important in the design of catheters for interventional neuroradiology, for mitigating complications of endovascular treatment. These dimensions and sex dimorphism must be considered during these procedures.

Bifurcation angle of basilar artery. The mean BA bifurcation angle was $99.9 \pm 32.9^{\circ}$, consistent with literature reports that they vary between $30-180^{\circ}$ (Vasovic et al., 2008). Bifurcation angle influences distribution of atherosclerosis. Wide angles are associated with atherosclerosis and aneurysms. Aneurysms for example originate from bifurcation angles of $90^{\circ}$, and their presence might lead to basilar angle deformations more frequently in cases having an angle less than $90^{\circ}$, than in cases larger than $90^{\circ}$ (Vasovic et al.). Observations of the current study that $80 \%$ have angles $>90^{\circ}$ suggest that they are more vulnerable to atherosclerosis and aneurysm.

Sexual Dimorphism. A notable observation of the current study is that length, diameter, confluence and bifurcation angles show sexual dimorphism. Similar sex differences have been reported in the anatomy of common carotid bifurcation (Krejza et al., 2006) and intracranial arteries (Lindekleiv et al., 2010). The basilar artery was significantly wider in females, concordant with reported wider internal carotid (Krejza et al.). It is, however, at variance with the conventional view that arteries are wider in males than in females (Lindekleiv et al.). Such anatomical differences impact the pathophysiology of vascular disease (Lindekleiv et al.) and may explain the sex differences in the prevalence and distribution of atheroma. The differences also need to be considered in the design of devices.

\section{CONCLUSION}

Vertebrobasilar arterial system in the black Kenyan population has geometric features that are considered to be risk factors for atherosclerosis. These features display sex dimorphism which neurosurgeons and radiologists should be aware of during their diagnostic and interventional procedures. Studies on prevalence of aneurysms and stroke in this vascular territory are recommended. Meantime, individuals with risk prone geometric factors should be followed up for atherosclerosis.

\section{ACKNOWLEDGMENTS}

We are grateful to Mr. Jacob Gimongo and Acleus Murunga for technical assistance and MS Catherine Chinga for typing the manuscript.

OGENG'O, J. A.; MWACHAKA, P. M.; ODHIAMBO, D. E.; SINKEET, S. R.; ELBUSAIDY, H.; OLABU, B. \& INYIMILI, M. Características geométricas del sistema arterial vertebrobasilar en kenianos negros adultos. Int. J. Morphol., 36(2):544-550, 2018.

RESUMEN: Las características geométricas del sistema vertebrobasilar influyen en la aparición de aterosclerosis en la circulación posterior, aneurismas, apoplejía, detectados durante procedimientos neurorradiológicos. Estas características muestran variación étnica, pero los datos de los africanos negros en el África Subsahariana son escasos. Este estudio tuvo como objetivo describir las características geométricas del sistema vertebrobasilar en una población negra de Kenia. Fue un estudio descriptivo cadavérico en el Departamento de Anatomía Humana de la Universidad de Nairobi. Se estudiaron 173 cerebros adultos (99 varones, 74 mujeres, rango de edad 20-79), fijados en formalina, de individuos que habían fallecido por causas no cerebrovasculares. Se midieron el nivel y ángulo de confluencia de la arteria vertebral, diámetro, longitud y bifurcación de la arteria basilar. Los datos fueron analizados por SPSS versión 21 para Windows. La prueba t de Student se utilizó para determinar las diferencias de sexo con un intervalo de confianza del $95 \%$. Los datos se presentan en macrografías, tablas y gráficos de barras. La confluencia de las arterias vertebra- 
les se produjo en el surco bulbopontino en el 79,8 \%; rostral al surco en $11,5 \%$ y caudal al surco en $8,7 \%$ de los casos. El ángulo medio de la confluencia de la arteria vertebral fue 46,70 y 68,90 en hombres y mujeres, respectivamente $(\mathrm{p} \leq 0,042)$. La longitud media de la arteria basilar fue de $26,8 \mathrm{~mm} ; 26,3 \mathrm{~mm}$ en hombres y $27,1 \mathrm{~mm}$ en mujeres $(\mathrm{p}=0,465)$. El diámetro promedio fue de 3,52 $\mathrm{mm} ; 3,32 \mathrm{~mm}$ en hombres y $3,72 \mathrm{~mm}$ en mujeres ( $\mathrm{p}=0,002)$. El ángulo medio de la bifurcación de la arteria basilar fue de 120,30 \pm 15,$2 ; 99.30 \pm 32,9$ en hombres y $140,30 \pm 16$, 1en mujeres $(\mathrm{p}=0,024)$. Era más amplio que $90^{\circ}$. En un 82,9\% de los hombres y $95,9 \%$ de las mujeres $(\mathrm{p}=0,032)$ se observó un ángulo más amplio que $90^{\circ}$. En $85(49,1 \%)$ fue más amplio que $120^{\circ}$. El sistema vertebrobasilar en la población de Kenia tiene características geométricas que constituyen factores de riesgo para la aterosclerosis. Estas características muestran dimorfismo sexual que puede explicar las diferencias en la prevalencia de aterosclerosis y aneurismas. Los neurocirujanos y los neurólogos deben tener en cuenta estas diferencias. Las personas con características geométricas propensas al riesgo deben ser seguidas por aterosclerosis.

PALABRAS CLAVE: Sistema vertebrobasilar; Geometría; Dimorfismo de sexo; Africanos.

\section{REFERENCES}

Aoki, J.; Iguchi, Y.; Kimura, K.; Shibazaki, K.; Iwanaga, T. \& Sakai, K. Diameter of the basilar artery may be associated with neurological deterioration in acute pontine infarction. Eur. Neurol., 63(4):221-6, 2010.

Bamford, J.; Sandercock, P.; Dennis, M.; Burn, J. \& Warlow, C. Classification and natural history of clinically identifiable subtypes of cerebral infarction. Lancet, 337(8756):1521-6, 1991.

Dodevski, A.; Lazareska, M.; Tosovska-Lazarova, D.; Zhivadinovik, J. \& Stojkoski, A. Basilar artery fenestration. Folia Morphol. (Warsz), 70(2):80-3, 2011

Efendic, A.; Isakovic, E.; Delic, J.; Mehinovic, A. \& Hrustic, A. Vascular geometry of vertebrobasilar tree with and without aneurysm. Med. Glas. (Zenica), 11(2):252-7, 2014.

Glagov, S.; Zarins, C.; Giddens, D. P. \& Ku, D. N. Hemodynamics and atherosclerosis. Insights and perspectives gained from studies of human arteries. Arch. Pathol. Lab. Med., 112(10):1018-31, 1988.

Ichikawa, H.; Mukai, M.; Katoh, H.; Hieda, S.; Murakami, H. \& Kawamura, M. Cerebral microbleeds and dilative remodeling of the basilar artery: a magnetic resonance imaging study. J. Stroke Cerebrovasc. Dis., 20(5):429-35, 2011.

Ikeda, K.; Nakamura, Y.; Hirayama, T.; Sekine, T.; Nagata, R.; Kano, O.; Kawabe, K.; Kiyozuka, T.; Tamura, M. \& Iwasaki, Y. Cardiovascular risk and neuroradiological profiles in asymptomatic vertebrobasilar dolichoectasia. Cerebrovasc. Dis., 30(1):23-8, 2010.

Koch, S.; Nelson, D.; Rundek, T.; Mandrekar, J. \& Rabinstein, A. Raceethnic variation in carotid bifurcation geometry. J. Stroke Cerebrovasc. Dis., 18(5):349-53, 2009.

Krejza, J.; Arkuszewski, M.; Kasner, S. E.; Weigele, J.; Ustymowicz, A.; Hurst, R. W.; Cucchiara, B. L. \& Messe, S. R. Carotid artery diameter in men and women and the relation to body and neck size. Stroke, 37(4):1103-5, 2006.

Lee, S. H.; Hur, N. \& Jeong, S. K. Geometric analysis and blood flow simulation of basilar artery. J. Atheroscler. Thromb., 19(4):397-405, 2012.

Lindekleiv, H. M.; Valen-Sendstad, K.; Morgan, M. K.; Mardal, K. A.; Faulder, K.; Magnus, J. H.; Waterloo, K.; Romner, B. \& Ingebrigtsen,
T. Sex differences in intracranial arterial bifurcations. Gend. Med., 7(2):149-55, 2010

Oladapo, O. O.; Olusakin, J.; Ogun, G. O. \& Akang, E. Atherosclerosis of the intracranial carotid arteries in Nigerians: A pilot autopsy study. Niger. J. Cardiol., 10(2):62-7, 2013.

Owolabi, M. O.; Akarolo-Anthony, S.; Akinyemi, R.; Arnett, D.; Gebregziabher, M.; Jenkins, C.; Tiwari, H.; Arulogun, O.; Akpalu, A.; Sarfo, F. S.; Obiako, R.; Owolabi, L.; Sagoe, K.; Melikam, S.; Adeoye, A. M.; Lackland, D.; Ovbiagele, B. \& Members of the H3Africa Consortium. The burden of stroke in Africa: a glance at the present and a glimpse into the future. Cardiovasc. J. Afr., 26(2 Suppl. 1):S27-38, 2015.

Pai, B. S.; Varma, R. G.; Kulkarni, R. N.; Nirmala, S.; Manjunath, L. C. \& Rakshith, S. Microsurgical anatomy of the posterior circulation. Neurol. India, 55(1):31-41, 2007.

Patel, S.; Zalavadiya, D.; Ganatra, D.; Nagdev, K. \& Vaniya, V. Morphometry of basilar artery in population of Gujarat. J. Anat. Soc. India, 64(1):62-6, 2015.

Pico, F.; Labreuche, J.; Gourfinkel-An, I.; Amarenco, P. \& GENIC Investigators. Basilar artery diameter and 5-year mortality in patients with stroke. Stroke, 37(9):2342-7, 2006.

Ravensbergen, J.; Krijger, J. K.; Hillen, B. \& Hoogstraten, H. W. The influence of the angle of confluence on the flow in a vertebro-basilar junction model. J. Biomech., 29(3):281-99, 1996.

Songur, A.; Gonul, Y.; Ozen, O. A.; Kucuker, H.; Uzun, I.; Bas, O. \& Toktas, M. Variations in the intracranial vertebrobasilar system. Surg. Radiol. Anat., 30(3):257-64, 2008.

Tanaka, M.; Sakaguchi, M.; Miwa, K.; Okazaki, S.; Furukado, S.; Yagita, Y.; Mochizuki, H. \& Kitagawa, K. Basilar artery diameter is an independent predictor of incident cardiovascular events. Arterioscler. Thromb. Vasc. Biol., 33(9):2240-4, 2013.

Ubogu, E. E. \& Zaidat, O. O. Vertebrobasilar dolichoectasia diagnosed by magnetic resonance angiography and risk of stroke and death: a cohort study. J. Neurol. Neurosurg. Psychiatry, 75(1):22-26, 2004.

Vasovic, L.; Jovanovic, I.; Ugrenovic, S.; Stojanov, D. \& Radovanovic, Z. Basilar bifurcation: a comparison of prenatal and postnatal cases. Neuroanatomy, 7:66-71, 2008.

Wankhede, H. A.; Hosmani, P. B. \& Nimje, D. A. Morphological study of the basilar artery in adult human cadavers. Int. J. Anat. Res., 2(3):497-502, 2014.

Wójtowitz, Z.; Zauska, S.; Kis, G. \& Sawa, J. The basilar artery of humans. Ann. Univ. Mariae Curie Sklodowska Med., 44:101-8, 1989.

Xu, Y.; Song, B.; Zhao, L.; Gao, Y.; Fang, H. \& Xu, Y. A review of vetebrobasilar dolichoectasia. Life Sci. J., 11(6):388-93, 2014.

Corresponding author:

Julius Ogeng'o

Department of Human Anatomy

University of Nairobi

KENYA

Email jogengo@uonbi.ac.ke

Received: $24-12-2017$

Accepted: 01-02-2018 